Jurnal Ilmu Sosial dan Pendidikan (JISIP)

Vol. 5 No. 3 Juli 2021

Terakreditasi Peringkat 5 (No. SK: 85/M/KPT/2020)

e-ISSN : 2656-6753, p-ISSN: 2598-9944

DOI: 10.36312/jisip.v5i3.2238/http://ejournal.mandalanursa.org/index.php/JISIP/index

\title{
Strategi Pengembangan Pariwisata Dalam Rangka Meningkatkan Pendapatan Asli Daerah Di Kabupaten Bangka
}

\author{
Syahbudin, Khasan Effendy, Kusworo \\ Email: Syahbudin.dino@gmail.com
}

\begin{tabular}{l}
\hline Article Info \\
Article history: \\
$\begin{array}{l}\text { Article Reseived : } 19 \text { July } 2021 \\
\text { Publication: } 20 \text { July } 2021\end{array}$
\end{tabular}

\section{Kata Kunci:}

Strategi, Pemerintahan Daerah, Pariwisata, SWOT, tes Litmus

\begin{abstract}
ABSTRAK
Fokus dalam penelitian ini adalah untuk mengkaji dan menganalisis strategi pengembangan pariwisata dalam rangka meningkatkan pendapatan asli daerah. Adapun konsep yang digunakan dalam penelitian ini adalah menggunakan teori Yoeti yang memperhatikan pariwisata dengan unsur-unsur : Industri pariwisata, Destinasi pariwisata, Kelembagaan pariwisata dan Pemasaran pariwisata. Penelitian ini menggunakan desain penelitian kualitatif deskriptif dan eksploratif dengan lokus 8 kecamatan di Kabupaten Bangka Provinsi Bangka Belitung. Teknik pengumpulan data dilakukan melalui wawancara, observasi, dokumentasi, triangulasi. Hasil penelitian mengungkapkan bahwa walaupun banyak objek wisata potensial di Kabupaten Bangka namun belum dikelola secara optimal. Untuk jumlah kunjungan wisatawan di Kabupaten Bangka tidak stabil setiap tahunnya karena mengalami kenaikan dan penurunan. Kondisi kelembagaan pariwisata di Kabupaten Bangka sudah cukup baik dimana banyak terdapat asosiasi kepariwisataan dan Lembaga-lembaga lain. Tetapi hal tersebut tidak diimbangi dengan kualitas sumber daya manusia dimana tingkat pendidikan aparatur kepariwisataan dan stakeholder yang terkait belum cukup secara kualitas maupun kuantitas. Pemasaran/promosi pariwisata di Kabupaten Bangka sudah banyak dilakukan baik dengan media cetak maupun elektonik (internet). Karena karakteristik wisatawan yang datang untuk berwisata di Kabupaten Bangka adalah wisatawan local menyebabkan pemasaran wisata berfokus hanya pada kalangan wisatawan local dan wisatawan nusantara. Sedangkan pertumbuhan wisatawan masih belum konsisten dimana terdapat kenaikan dan penurunan jumlah kunjungan terlebih sejak tahun 2020 pada situasi pademi covid terdapat penurunan jumlah kunjungan sehingga sangat berdampak pada usaha pariwisata di Kabupaten Bangka yang pada akhirnya berkorelasi terhadap penerimaan dari pajak dan retribusi daerah sebagai komponen Pendapatan Asli Daerah di dalam APBD. Berdasarkan identifikasi isu-isu dalam pengembangan pariwisata di Kabupaten Bangka yang dianalisis dengan metode SWOT dan kemudian dilakukan pengujian dengan tes litmus. Dari hasil tes tersebut dihasilkan isu yang dikategorikan sangat prioritas, yaitu mengembangkan objek wisata dengan berkerjasama pihak lainnya seperti BUMN, Swasta dan Masyarakat.
\end{abstract}

This is an open access article under the Lisensi Creative Commons AtribusiBerbagiSerupa 4.0 Internasional

Corresponding Author:

Syahbudin

Email: Syahbudin.dino@gmail.com

\section{PENDAHULUAN}

Dalam rangka mewujudkan tatanan penyelenggaraan pemerintahan sesuai dengan tuntutan reformasi, pemerintah antara lain telah mengeluarkan Undang-Undang Nomor 23 Tahun 2014 yang merupakan revisi Undang-Undang Nomor 32 Tahun 2004 tentang Pemerintahan Daerah. Prinsip otonomi daerah menggunakan prinsip otonomi nyata, bertanggung jawab dan seluas-luasnya dalam arti daerah diberikan kewenangan mengurus dan mengatur semua urusan pemerintahan di luar yang menjadi kewenangan pemerintah pusat. 
Daerah memiliki kewenangan membuat kebijakan daerah untuk memberi pelayanan, meningkatkan peran serta, prakarsa dan pemberdayaan masyarakat yang bertujuan pada peningkatan kesejahteraan rakyat.

Dengan otonomi daerah, setiap daerah dapat menggali potensi yang bisa dikembangkan, sehingga perkembangan masing-masing daerah dapat meningkat pesat. Terdapat berbagai sektor yang dapat dikembangkan, diantaranya adalah: sektor perdagangan, sektor jasa, sektor pertanian, sektor pariwisata dan lain-lain. Peneliti lebih tertarik dari salah satu sektor tersebut yaitu sektor pariwisata, karena Kabupaten Bangka memiliki potensi sektor pariwisata yang besar yang dapat dikembangkan menjadi produk unggulan daerah selain sektor pertambangan timah yang selama ini mempengaruhi perekonomian masyarakat.

Provinsi Kepulauan Bangka Belitung memiliki potensi besar bagi perkembangan pariwisata daerah yang terdiri dari 4 kabupaten yang memiliki potensi terbesar yang salah satunya adalah Kabupaten Bangka. Potensi itu terdiri dari wisata alam dan budaya dan atau buatan. Kondisi pariwisata di Kabupaten Bangka seharusnya dapat maksimal di lakukan bila dilihat dari jumlah destinasinya, sektor pemasarannya, sektor industrinya serta lembaga pariwisatanya, namun pada kenyataanya kondisi perkembangan pariwisata belum secara menyuluruh dapat diketahui oleh pemerintah daerah sendiri, ini dapat dilihat pada banyaknya objek wisata yang kondisi sekarang belum diketahui perkembanganya serta rencana perkembangannya, sarana promosi yang dilakukan pada objek-objek wisata tentu berbeda-beda

Pengaruh sektor pariwisata tentunya berdampak pada berbagai hal, salah satunya peningkatan Pendapatan Asli Daerah yang secara langsung maupun tidak langsung mempengaruhi tingkat perekonomian yang ada pada wilayah sekitar objek wisata tersebut, yang dimana masyarakat dapat berperan langsung pada berbagai jasa yang berkaitan dengan pengembangan pariwisata itu sendiri

\subsection{Rumusan Masalahan}

Berdasarkan latar belakang dan beberapa masalah yang telah diidentifikasi di atas, dalam penelitian ini penulis merumuskan permasalahan sebagai berikut :

1. Bagaimana kondisi pengembangan pariwisata terhadap Pendapatan Asli Daerah di Kabupaten Bangka?

2. Faktor-faktor apa yang mempengaruhi perkembangan pariwisata dalam rangka peningkatan Pendapatan Asli Daerah di Kabupaten Bangka?

3. Bagaimana strategi yang dilakukan pada sektor pariwisata dalam rangka peningkatan Pendapatan Asli Daerah di Kabupaten Bangka?

\section{METODE PENELITIAN}

Penggunaan metode penelitian merupakan suatu langkah yang harus ditempuh, agar hasilhasil yang sudah terseleksi dapat terjawab secara valid, reliabel dan obyektif, dengan tujuan dapat ditemukan, dibuktikan dan dikembangkan suatu pengetahuan, sehingga dapat digunakan untuk memahami, memecahkan, dan mengantisipasi masalah yang ada. Berdasarkan permasalahan dan fokus penelitian, maka metode penelitian yang digunakan dalam penelitian ini adalah kualitatif-deskriptif.

Sugiyono mendefinisikan metode kualitatif sebagai metode penelitian yang digunakan untuk meneliti pada kondisi obyek yang alamiah (sebagai lawannya adalah eksperimen) dimana peneliti adalah sebagai instrumen kunci, teknik pengumpulan data dilakukan secara triangulasi (gabungan), analisis data bersifat induktif, dan hasil penelitian kualitatif lebih menekankan makna daripada generalisasi.

Penelitian kualitatif dapat diasumsikan ke dalam kategori penelitian partisipatif dimana desain penelitiannya memiliki fleksibilitas atau sangat mungkin terjadi perubahan untuk menyesuaikan dengan pedoman yang disusun berdasarkan fenomena sebenarnya di lokasi penelitian. Oleh sebab itu, sang peneliti tidak mengetahui berkaitan dengan informan penelitian serta pertanyaan yang akan diajukan, tetapi dalam proses penelitian diperbolehkan melakukan 
perubahan terhadap desain penelitian. Berdasarkan pendapat tersebut dalam penelitian ini peneliti menggunakan metode penelitian kualitatif dengan pendekatan deskriptif.

Data primer dalam penelitian ini diperoleh melalui wawancara serta catatan-catatan dari hasil pengamatan di lapangan. Penulis mengambil data wawancara dengan para informan yang bertindak selaku pelaksana dan kelompok sasaran dari kebijakan. Menurut Rusidi informan adalah sumber data primer yang mampu memberikan informasi mengenai diri/keadaan orang lain, atau memberikan informasi tentang situasi dan kondisi lingkungannya.

Secara umum ada dua teknik sampling yang dapat digunakan, yaitu sampling probabilitas yang cenderung bersifat kuantitatif dengan analisis statistik, dan teknik sampling nonprobabilitas yang cenderung bersifat kualitatif. Untuk menjawab permasalahan khusus yang sulit diungkapkan dan tidak mudah dianalisis secara statistik, maka teknik sampling nonprobabilitas akan lebih tepat dan dapat lebih berguna dalam proses pengumpulan data. Untuk lebih jelasnya teknik sampling non-probabilitas dapat di lihat pada tabel berikut ini :

Tabel 1. Jenis-jenis Sampling dalam Teknik Sampling Non-Probabilitas

\begin{tabular}{|c|c|c|}
\hline No. & Jenis Sampling & Prinsip Pelaksanaan \\
\hline$(1)$ & $(2)$ & $(3)$ \\
\hline 1. & $\begin{array}{l}\text { Haphazard } \\
\text { (sembarang, } \\
\text { seadanya) }\end{array}$ & $\begin{array}{l}\text { Mengambil berbagai kasus dengan cara- } \\
\text { cara yang disukai peneliti. }\end{array}$ \\
\hline 2. & $\begin{array}{l}\text { Quota (memilih / } \\
\text { menentukan } \\
\text { kategori) }\end{array}$ & $\begin{array}{c}\text { Mengambil sejumlah kasus diawali } \\
\text { dengan menentukan beberapa kategori } \\
\text { yang dapat menunjukkan perbedaan } \\
\text { populasi, }\end{array}$ \\
\hline 3. & $\begin{array}{c}\text { Purposive } \\
\text { (menentukan / } \\
\text { menyesuaikan) }\end{array}$ & $\begin{array}{c}\text { Mengambil semua kasus yang mungkin } \\
\text { sesuai dengan kriteria tertentu melalui } \\
\text { penggunaan berbagai metode. }\end{array}$ \\
\hline 4. & $\begin{array}{l}\text { Snowball (bola } \\
\text { salju) }\end{array}$ & $\begin{array}{c}\text { Mengambil sejumlah kasus melalui } \\
\text { hubungan keterkaitan dari satu orang } \\
\text { dengan orang yang lain atau satu kasus } \\
\text { dengan kasus lain, }\end{array}$ \\
\hline 5. & $\begin{array}{l}\text { Deviant Case (kasus } \\
\text { penyimpangan) }\end{array}$ & $\begin{array}{c}\text { Mengambil kasus-kasus yang secara } \\
\text { substansi berbeda dari pola-pola yang } \\
\text { dominan }\end{array}$ \\
\hline 6. & $\begin{array}{l}\text { Sequential } \\
\text { (berurutan) }\end{array}$ & $\begin{array}{c}\text { Mengambil kasus-kasus sampai tidak ada } \\
\text { informasi tambahan atau karakteristik - } \\
\text { karakteristik yang baru }\end{array}$ \\
\hline 7. & $\begin{array}{l}\text { Theoretical (bersifat } \\
\text { teoritik) }\end{array}$ & $\begin{array}{c}\text { Mengambil kasus-kasus yang akan } \\
\text { membantu memunculkan gambaran yang } \\
\text { penting secara teoritik mengenai suatu } \\
\text { topik / setting tertentu }\end{array}$ \\
\hline
\end{tabular}

Sumber : Neuman Social Research Methods: Qualitative and Quantitative Approch

Dalam penelitian kualitatif ini, teknik sampling yang digunakan adalah proposive sampling. Seperti yang dijelaskan pada tabel diatas proposive sampling adalah teknik pengambilan sampel dari sember data dengan pertimbangan tertentu. Pertimbangan tersebut misalnya sampel tersebut dianggap sebagai orang yang paling tahu mengenai apa yang diharapkan peneliti atau orang yang mempunyai kekuasaan terhadap objek penelitian sehingga mudah untuk mengamati objek/fenomena yang diteliti.

Selanjutnya menurut Sugiyono informan sebaiknya memenuhi kriteria sebagai berikut (a) 
Mereka yang menguasai dan memahami sesuatu melalui proses enkulturasi, sehingga sesuatu itu bukan sekedar diketahui, tetapi juga dihayatinya; (b) Mereka yang tergolong masih sedang berkecimpung atau terlibat pada kegiatan yang tengah diteliti; (c) Mereka yang mempunyai waktu yang memadai untuk dimintai informasi; (d) Mereka yang tidak cenderung menyampaikan informasi hasil "kemasannya" sendiri; (e) Mereka yang pada mulanya tergolong "cukup asing" dengan peneliti sehingga lebih menggairahkan untuk dijadikan semacam guru atau narasumber.

Informan dapat dinyatakan sebagai orang nomor satu setelah peneliti karena tanpa informan peneliti akan kebingungan dalam menungkapkan permasalahan. Pada penelitian kualitatif, informan yang dijadikan sebagai sumber adalah informan yang kompeten, memiliki relevansi dengan setting sosial yang diteliti, di mana setting sosial itu sendiri menyangkut situasi dan kondisi lingkungan tempat yang berkaitan dengan penelitian.

\section{HASIL PENELITIAN dan PEMBAHASAN}

\subsection{Hasil penelitian}

3.1.1. Kondisi Pengembangan Pariwisata terhadap Penerimaan Pendapatan Asli Daerah

Berdasarkan hasil penelitian yang telah dibahas sebelumnya pada bagian ini akan dibahas hasil-hasil dari penelitian disesuaikan dengan konsep pariwisata yang dijelaskan oleh Yoeti yang menyatakan bahwa:

"Pariwisata adalah suatu perjalanan yang dilakukan untuk sementara waktu, yang diselenggarakan dari satu tempat ketempat yang lain, dengan maksud bukan untuk berusaha atau mencari nafkah ditempat yang dikunjungi tetapi semata-mata untuk menikmati perjalanan hidup guna bertamasya dan rekreasi atau memenuhi keinginan yang beraneka ragam.indikator pariwisata meliputi:

1. Industri pariwisata

2. Destinasi pariwisata

3. Kelembagaan pariwisata

4. Pemasaran pariwisata"

Berdasarkan penapat tersebut dapat disimpulkan bahwa ada 4 (indikator) pokok gagasan yang dibahas dalam pariwisata yaitu Industri pariwisata, Destinasi pariwisat, Kelembagaan pariwisata dan Pemasaran pariwisata"

\subsubsection{Pembangunan Industri Pariwisata}

Usaha pariwisata dalam hal ini yaitu paket wisata yang ditawarkan khusus untuk wilayah Kabupaten Bangka cukup banyak pilihan diantaranya paket wisata yang khusus hanya mengunjungi Kabupaten Bangka saja ataupun paket wisata yang termasuk dengan wisata ke Belitung juga. Paket wisata ke Kabupaten Bangka sudah banyak ditawarkan oleh agen-agen travel dengan terdapat pilihan berbagai paket wisata.

\subsubsection{Destinasi Pariwisata}

Kabupaten Bangka memiliki Objek wisata yang cukup bervariasi dan jumlahnya banyak. Pemerintah Kabupaten Bangka mencatat sedikitnya 41 (empat puluh satu) Objek Wisata yang terdapat di Kabupaten Bangka baik yang sudah dikembangkan maupun yang belum dikembangkan. Objek wisata terdiri dari beragam jenis diantaranya wisata alam, wisata budaya, wisata sejarah, wisata religi dan wisata agro. Sebagaimana Objek Wisata di Kabupaten Bangka secara umum daya tarik wisata di Kabupaten Bangka sebagian besar merupakan wisata alam dan Sejarah. Walaupun banyak objek wisata potensial di Kabupaten Bangka namun belum dikelola secara optimal. Untuk jumlah kunjungan wisatawan di Kabupaten Bangka tidak stabil setiap tahunnya karena mengalami kenaikan dan penurunan.

Langkah Pemerintah Kabupaten Bangka menjadikan sektor pariwisata sebagai salah satu sektor andalan dalam menopang perekonomian merupakan langkah yang 
tepat. Kabupaten Bangka memiliki banyak daya tarik wisata yang menarik untuk dikembangkan, seperti wisata alam, wisata sejarah, wisata seni dan budaya atau wisata lainnya

\subsubsection{Kelembagaan Pariwisata}

Kondisi kelembagaan pariwisata di Kabupaten Bangka sudah cukup baik dimana banyak terdapat asosiasi kepariwisataan dan Lembaga-lembaga lain. Selain asosiasi kepariwisataan terdapat juga kelembagaan lain terkait pariwisata di Kabupaten Bangka yaitu Kelompok Sadar Wisata (POKDARWIS) Kabupaten Bangka yang tersebar di 8 Kecamatan. Tujuan pembentukan Pokdarwis ini untuk meningkatkan posisi dan peran masyarakat sebagai subjek atau pelaku penting dalam pembangunan kepariwisataan. Diharapkan Pokdarwis dapat bersinergi dan bermitra dengan pemangku kepentingan terkait untuk meningkatkan kualitas perkembangan kepariwisataan daerah. Tetapi jumlah Lembaga pariwisata yang relative banyak tersebut tidak diimbangi dengan kualitas sumber daya manusia dimana tingkat pendidikan aparatur kepariwisataan dan stakeholder yang terkait belum cukup secara kualitas maupun kuantitas.

\subsubsection{Pemasaran Pariwisata}

Pemasaran/promosi pariwisata di Kabupaten Bangka sudah banyak dilakukan baik dengan media cetak maupun elektonik (internet). Saat ini upaya pemasaran yang dilakukan Pemerintah Kabupaten Bangka cenderung meningkat. Ini dibuktikan dengan banyaknya promosi-promosi obyek wisata yang ada di Kabupaten Bangka baik itu melalui media sosial (facebook, twitter, Instagram) dan sebagainya. Bahkan saat ini sudah ada website pariwisata yang menjabarkan kondisi pariwisata di Kabupaten Bangka melalui website www.visitbangkabelitung. com dimana dalam web ini tidak hanya menjabar mengenai kondisi pariwisata Kabupaten Bangka namum kondisi pariwisata secara keseluruhan yang mencakup Kepulauan Bangka Belitung.

Karena karakteristik wisatawan yang datang untuk berwisata di Kabupaten Bangka adalah wisatawan local menyebabkan pemasaran wisata berfokus hanya pada kalangan wisatawan local dan wisatawan nusantara. Sedangkan pertumbuhan wisatawan masih belum konsisten dimana terdapat kenaikan dan penurunan jumlah kunjungan terlebih sejak tahun 2020 pada situasi pademi covid terdapat penurunan jumlah kunjungan sehingga sangat berdampak pada usaha pariwisata di Kabupaten Bangka yang pada akhirnya berkorelasi terhadap penerimaan dari pajak dan retribusi daerah sebagai komponen Pendapatan Asli Daerah di dalam APBD

\subsubsection{Faktor-faktor Yang Mempengaruhi Pengembangan Pariwisata Kabupaten Bangka}

Faktor-faktor yang mempengaruhi perkembangan pariwisata di Kabupaten Bangka di bagi menjadi factor pendorong dan factor penghambat. Berdasarkan hasil penelitian ditemukan beberapa faktor yang menjadi pendukung/pendorong dalam pengembangan pariwisata di Kabupaten Bangka, yaitu:

\section{Daya dukung Prasarana;}

Secara umum daya dukung infrastruktur terhadap pengembangan pariwisata di Kabupaten Bangka telah terlayani dengan jaringan jalan yang memadahi, hanya beberapa lokasi yang masih perlu ditingkatkan. Ketersediaan infrastruktur tersebut sayangnya belum diimbangi dengan sistem transportasi yang menunjang keberadaan lokasi kunjungan wisata yang tersebar di berbagai daerah, dimana sebagian besar adalah wisata alam yang didominasi oleh alam pantai. Oleh karena itu pengembangan dan peningkatan infrastruktur untuk menunjang pariwisata alam pantai khususnya pariwisata bahari masih perlu mendapat perhatian. Sementara seperti jaringan listrik, telepon dan air bersih juga masih sangat terbatas.

\section{Daya dukung industri pariwisata;}

Pemerintah melalui Dinas Pariwisata terus berupaya dalam pengembangan 
paket objek wisata. Dalam hal ini paket objek wisata yang lengkap berarti tidak hanya objeknya saja yang dikembangkan tetapi faktor penunjang juga sangat penting untuk dikembangkan seperti industri pariwisata. Adanya penunjang jasa industri pariwisata yang dimiliki menjadi faktor pendukung kekuatan pariwisata di Kabupaten Bangka. Namun masih ada beberapa tempat wisata yang belum sepenuhnya memiliki industri pariwisata yang lengkap.

\section{Daya dukung masyarakat;}

Berdasarkan hasil penelitian menunjukkan bahwa terdapat pengaruh yang sangat besar dari faktor daya dukung prasarana, daya dukung industri pariwisata dan daya dukung masyarakat. Prasana yang memadai ditunjang dengan industry pariwisata yang dikelola dengan baik sangat penting peranannya dalam eksitensi pariwisata secara berkelanjutan. selain itu daya dukung masayrakat merupakan modal dasar sekaligus kekauatan (strength) dalam industry pariwisata. Budaya masyarakat bangka yang bersifat terbuka dan terbiasa hidup dalam keanekaragaman etnis membuat suatu pola kehidupan yang mudah menerima perbedaan budaya yang dimana hal tersebut sangat dibutuhkan dalam industri pariwisata. Apabila beberapa hal tersebut dikelola dengan baik akan menjadi kekuatan dalam menyusun formula dalam rangka meningkatkan pendapatan asli daerah (PAD)

\section{Kebijakan teknis pemerintah;}

Sesuai yang tertuang dalam Renstra Dinas Pariwisata dan Kebudayaan Kabupaten Bangka Tahun 2021-2023 bahwa kebijakan merupakan ketentuan yang telah ditetapkan untuk dijadikan pedoman/petunjuk dalam pengembangan ataupun pelaksanaan program/kegiatan guna terciptanya kelancaran dan keterpaduan dalam perwujudan sasaran, tujuan serta pencapaian visi dan misi Dinas Kebudayaan dan Pariwisata Kabupaten Bangka. Adanya kebijakan yang dikeluarkan pemerintah khususnya terkait pengembangan pariwisata menjadikan peluang bagi stakeholder dan masyarakat untuk mengembangkan potensi wisata yang membawa dampak positif bagi Pendapatan Asli Daerah (PAD). Selain itu pontensi wisata apabila dikolala dengan baik akan meningkatkan kesejahteraan masyarakat. Kebijakan pemerintah juga merupakan faktor pendukung perkembangan industri pariwisata. Salah satu kebijakan pemerintah adalah adanya aturan atau pedoman rencana pembangunan pariwisata yang dirumuskan oleh pemerintah, dan salah satu peraturan/kebijakan pemerintah yang terkait dengan industri pariwisata adalah memiliki, memperkenalkan, memberkahi, dan mempertahankan nilai sejarah. budaya lokal dan keindahan alam, Mendukung upaya penyediaan lapangan kerja yang pada akhirnya dapat meningkatkan pendapatan masyarakat di daerah terkait. Dan mereview masterplan pariwisata Kabupaten Bangka.

\section{Kerjasama/kebijakan dengan pihak lain;}

Kemitraan atau patnership disebut juga sebagai hubungan antara pemerintah, sektor swasta dan masyarakat guna mencapai tujuan bersama. Dalam hal kemitraan yang dilakukan pemerintah, sektor swasata dan masyarakat dalam mengmebangkan objek wisata akan membawa dampak yang positif pada proses pengembangan tesebut. Oleh karena itu adanya kerja sama atau mitra menjadi faktor yang sangat penting dalam pengembangan daerah wisata. Adanya kemitraan menjadi peluang yang harus dimanfaatkan oleh pemerintah dan masyarakan.

\section{Keamanan dan keramahan penduduk setempat;}

Salah satu faktor pendukung kegiatan wisata dengan memperhatikan kondisi masyrakat yang berada di tempat wisata itu sendiri. Masyarakat dan penduduk daerah kabupaten bangka sangat terkenal akan keramahan dan keamanannya. Hal ini menjadi peluang untuk menjadi daya tarik wisatwan datang dan berwisata di kabupaten bangka. 


\section{Keinginan berwisata dan berkreasi.}

Kepadatan aktivitas yang dilakukan sebagian besar masyarakat yang bekerja di perkantoran terlebih dikota-kota besar, sehingga membutuhkan refreshing sejenak untuk menghilangkan kepenatan selama bekerja yang secra langsung kebutuhan akan tempat-tempat wisata akan meningkat. Hal ini menjadi peluang bagi daerah-daerah yang memiliki pontensi kepariwisataan yang baik. Dalam hal ini tingginya tingkat keinginan berwisata sangat penting dalam pengembangan sektor wisata. Daya saing pariwisata semakin tinggi sehingga pemerintah daerah harus bekerja kerasa dalam menghadapi persaingan dunia pariwisata dengan terus mengembangkan potensi-potensi wisata yang dimiliki.

Sedangkan faktor penghambat dalam pengembangan pariwisata di Kabupaten Bangka, yaitu:

\section{a. Lemahnya Promosi dan Event Pariwisata;}

Salah satu penyebab masih rendahnya kunjungan wisatawan baik nusantara maupun manca negara yaitu masih rendahnya dalam mempromosikan objek wisata dan event-event pariwisata baik nasional maupun internasional. Selain itu belum secara optimal memanfaatkan media-media elektronik (online)

\section{b. Rendahnya SDM pariwisata;}

Rendahnya sumber daya manusia yang dimiliki akan menyebabkan pelaksanaan pengembangan pariwisata tidak berjalan secara optimal. Rendahnya kualitas sumberdaya manusia atau aparatur pemerintah akan berpengaruh terhadap kinerja dalam pengembangan pariwisata. Serta akan berdapak pada kualitas dan kemajuan sektor pariwisata.

\section{c. Belum optimalnya pengembangan sarana dan prasarana;}

Masih minimnya sarana dan prasarana di tempat-teampat objek wisata seperti seperti toilet, toilet, tempat ibadah, dan fasilitas ekonomi seperti kantin atau kafe, restoran dan tempat membeli oleh-oleh. Hal ini disebabkan karena masih terbatasnya dana anggaran anggaran yang ada di Kabupaten maupun Provinsi.

\section{d. Potensi wisata belum digali secara maksimal;}

Potensi pariwisata memegang peranan penting dalam pengembangan industri pariwisata itu sendiri, karena apabila potensi yang ada tidak dikelola maka perkembangan industri pariwisata dapat menemui kendala. lemahnya pembangunan pariwisata oleh pemerintah penyebabkan masih banyaknya tempat-tempat wisata yang masih belum dikelola.

e. Rendahnya kesadaran masyarakat akan potensi wisata;

Kondisi sebagian besar masyarakat di sekitar kawasan wisata di Kabupaten Bangka masih tergolong rendah, sehingga memiliki kemampuan menyerap pengetahuan tentang pengembangan potensi pariwisata untuk mendorong perkembangan pariwisata dan sektor produksi. masih sangat rendah Sumber daya manusia untuk mengelola industri pariwisata dikatakan masih sangat langka. Sebagian besar masyarakat yang ada di Kabupaten bangka belum sadar akan potensi pariwisata karena sebagian besar masyarakat masih terbuai oleh manisnya hasil sektor pertambangan. Sehingga kesadaran akan pentingnya pengembangan potensi pariwisata baik di desa kecamatan maupun kota masih sangat rendah.

\section{f. Adanya wisata lain yang sejenis;}

Berkebangnya objek wisata yang ada di setiap kabupaten yang ada di Provinsi Kepulauan Bangka Belitung akan menyebabkan daya saing semakin meningkat. Banyaknya objek wisata membuat banyak opsi bagi pengunjung untuk memilih objek wisata sesuai dengan yang diinginkan. Oleh sebab itu dalam hal ini pengelola objek wisata harus berlomba-lomba meningkatkan dan 
mengembangkan potensi wisata yang dimiliki agar dapat bersaing baik didaerah maupun nasional.

g. Kerusakan dan Pencemaran Lingkungan;

Di Kabupaten Bangka banyak potensi-potensi wisata baik pantai maupun wisata-wisata lainya yang sanggat alami terjadi kerusakan akibat ulah manusia yang tidak bertanggung jawab. Kerusakat itu diakibatkan semakin maraknya tambang-tambang timah Kerusakan dan Pencemaran Lingkungan merupakan isu utama, terutama di kabupaten bangka yang merupakan daerah penambangan timah. Untuk menciptakan sinergi antara industry pariwisata dan industry penambangan sangat sulit dan dilematis, mengingat pengembangan pariwisata dan penambangan sifatnya sangat bertolak belakang. Berdasarkan hal tersebut perlu adanya bargaining / tawar menawar dalam hal regulasi dan lainnya sehingga kedua hal tersebut dapat saling berjalan mengingat ada kepentingan strategis nasional dalam hal kegiatan penambangan di Kabupaten Bangka.

h. Kurangnya kesadaran akan pariwisata

Kurangnya kesadaran masyarakat disebabkan kurangnya edukasi terhadap potensi pariwisata. Sector penambangan yang masih menjadi idola masyarakat turut andil dalam memberikan pandangan terhadap masayarakat mengenai kesadaran akan pariwisata. Berbeda dengan daerah Belitung dimana masyarakatnya sudah merasakan manfaat dari pariwisata.

\subsection{Pembahasan}

3.2.1. Strategi yang dilakukan pada sektor pariwisata dalam rangka peningkatan Pendapatan Asli Daerah di Kabupaten Bangka.

Memperhatikan potensi objek wisata di Kabupaten Bangka untuk dikembangkan yang telah dibahas potensial terhadap penerimaan Pendapatan Asli Daerah dari sector pariwisata. Sedangkan pengelolaan pariwisata belum optimal dilakukan untuk itu diperlukan strategi agar potensi pariwisata tersebut dapat memberikan sumbangan yang berarti dalam APBD kabupaten Bangka. Berdasarkan hasil penelitian kemudian peneliti mengidentifikasikan beberapa isu kedalam analisis SWOT sebagai berikut:

Tabel 2. Matriks Analisis SWOT Strategi Pengembangan Pariwisata di Kabupaten Bangka

\begin{tabular}{|c|c|c|}
\hline INTERNAL & $\begin{array}{l}\text { STRENGHTS (S) } \\
\text { - Daya Dukung Infrastruktur } \\
\text { - Daya Dukung Industri } \\
\text { - Daya dukung Masyarakat } \\
\text { - Kondisi wilayah dan keadan fisik sangat } \\
\text { alamiah dan berpotensi untuk kegiatan } \\
\text { wisata. }\end{array}$ & $\begin{array}{l}\text { WEAKNES }(\mathbf{W}) \\
\text { - Lemahnya Promosi dan } \\
\text { Event Pariwisata } \\
\text { - Rendahnya SDM } \\
\text { Pariwisata } \\
\text { - Belum optimalnya } \\
\text { pengembangan sarana } \\
\text { dan prasarana } \\
\text { - Pontensi Wisata Belum } \\
\text { digali Secara Maksimal }\end{array}$ \\
\hline EKTERNAL & & \\
\hline $\begin{array}{l}\text { OPPORTUNIT } \\
\text { ES }(\mathbf{O}) \\
\text { - } \text { Kebijakan } \\
\text { teknis } \\
\text { Pemerintah } \\
\text { - } \text { Kerjasama/ke } \\
\text { mintraan } \\
\text { dengan pihak }\end{array}$ & $\begin{array}{l}\text { STRATEGI (SO) } \\
\text { - } \\
\text { Mengembangkan Objek Wisata } \\
\text { selakaligus meningkatkan Sarana dan } \\
\text { Prasarna penunjang objek wisata. } \\
\text { - } \\
\text { Mengembangkan Objek Wisata dengan } \\
\text { menggandeng pihak lainnya seperti } \\
\text { BUMN, Swasta dan Masyrakat. }\end{array}$ & $\begin{array}{l}\text { STRATEGI WO } \\
\text { - Memperbanyak event } \\
\text { kepariwisataan } \\
\text { berskala regional, } \\
\text { nasional dan } \\
\text { internasional dan } \\
\text { meningkatkan promosi } \\
\text { wisata melalui media }\end{array}$ \\
\hline
\end{tabular}




\begin{tabular}{|c|c|c|}
\hline $\begin{array}{l}\text { lain } \\
\text { - Keamanan } \\
\text { dan } \\
\text { keramahan } \\
\text { penduduk } \\
\text { setempat } \\
\text { - Keinginan } \\
\text { berwisata dan } \\
\text { berekreasi }\end{array}$ & & $\begin{array}{l}\text { sosial. } \\
\text { - Melaksanakan } \\
\text { pembinaan kepada } \\
\text { kelompok sadar wisata }\end{array}$ \\
\hline $\begin{array}{l}\text { THREATS (T) } \\
\text { - Adanya } \\
\text { wisata lain } \\
\text { yang sejenis } \\
\text { - Kerusakan } \\
\text { dan } \\
\text { Pencemaran } \\
\text { Lingkungan } \\
\text { - Kurangnya } \\
\text { kesadaran } \\
\text { akan } \\
\text { pariwisata }\end{array}$ & $\begin{array}{l}\text { STRATEGI (ST) } \\
\text { - Meningkatkan daya tarik objek wisata } \\
\text { dengan atraksi wisata. }\end{array}$ & $\begin{array}{l}\text { STRATEGI (WT) } \\
\text { - Meningkatkan Kualitas } \\
\text { SDM Kepariwisataan }\end{array}$ \\
\hline
\end{tabular}

Langkah selanjutnya dalam menemukan strategi yang paling prioritas dilakukan pengujian sesuai dengan bagaimana isu-isu yang telah didapat harus sesuai dengan kondisi dan situasi yang dapat sesegera mungkin untuk dilaksanakan dengan menggunakan tes litmus yang telah disusun 13 pertanyaan sesuai dengan locus dan focus penelitian yang dilakukan yaitu Kabupaten Bangka. Sebelum melakukan pengujian tes litmus tersebut isu-isu yang telah didapat dikolomkan menjadi urutan isu sehingga lebih memudahkan peneliti melakukan pengujian.

Untuk pengujian dengan tes litmus dapat dilihat pada table berikut ini:

Tabel 3. Test Litmus

\begin{tabular}{|c|c|c|c|c|c|c|c|}
\hline \multirow{2}{*}{ No. } & \multirow{2}{*}{ Pertanyaan Pokok } & \multicolumn{6}{|c|}{ Strategi } \\
\hline & & Isu 1 & Isu 2 & Isu 3 & Isu 4 & Isu 5 & Isu 6 \\
\hline 1 & 2 & 3 & 4 & 5 & 6 & 7 & 8 \\
\hline 1 & $\begin{array}{l}\text { Kapan isu tersebut mampu } \\
\text { dilaksanakan oleh Pemerintah Daerah } \\
\text { Kabupaten Bangka? }\end{array}$ & 1 & 3 & 2 & 1 & 2 & 1 \\
\hline 2 & $\begin{array}{l}\text { Seberapa luas pengaruh isu tersebut } \\
\text { terhadap Pemerintah Daerah Kabupaten } \\
\text { Bangka? }\end{array}$ & 2 & 3 & 1 & 2 & 2 & 1 \\
\hline 3 & $\begin{array}{l}\text { Seberapa besar resiko / peluang } \\
\text { finansial bagi Pemerintah Daerah } \\
\text { Kabupaten Bangka? }\end{array}$ & 2 & 2 & 3 & 1 & 3 & 1 \\
\hline 4 & $\begin{array}{l}\text { Apakah strategi bagi pemecahan isu } \\
\text { tersebut memerlukan persyaratan: }\end{array}$ & & & & & & \\
\hline & $\begin{array}{l}\text { a. Pengembangan tujuan dan } \\
\text { program pengembangan baru? } \\
\text { b. Perubahan yang nyata dalam hal } \\
\text { sumber pajak/ pembiayaan? }\end{array}$ & 2 & 2 & 1 & 2 & $\begin{array}{l}3 \\
3\end{array}$ & 1 \\
\hline
\end{tabular}




\begin{tabular}{|l|l|l|l|l|l|l|l|} 
& $\begin{array}{l}\text { c. Perubahan yang nyata dalam hal } \\
\text { perubahan perundang-undangan? } \\
\text { d. Perubahan (modifikasi) fasilitas } \\
\text { utama? }\end{array}$ & 1 & 2 & 2 & 3 & 1 & 1 \\
\hline e. Penambahan staf yang nyata? & 2 & 2 & 2 & 2 & 2 & 3 \\
\hline 5 & $\begin{array}{l}\text { Bagaimana pelaksanaan yang paling } \\
\text { sesuai tehadap pemecahan isu tersebut? }\end{array}$ & 1 & 3 & 1 & 1 & 2 & 1 \\
\hline 6 & $\begin{array}{l}\text { Siapa yang dapat memutuskan } \\
\text { pemecahan isu tersebut? }\end{array}$ & 2 & 3 & 2 & 1 & 2 & 2 \\
\hline 7 & $\begin{array}{l}\text { Apakah konsekuensi yang terjadi jika } \\
\text { isu tersebut tidak ditangani oleh } \\
\begin{array}{l}\text { Pemerintah Daerah Kabupaten } \\
\text { Bangka? }\end{array}\end{array}$ & 2 & 2 & 2 & 2 & 2 & 2 \\
\hline $\begin{array}{l}\text { Seberapa banyak dinas lain yang } \\
\text { terpengaruh dan terlibat dalam } \\
\text { pemecahan isu tersebut? }\end{array}$ & 2 & 3 & 2 & 1 & 2 & 1 \\
\hline 9 & $\begin{array}{l}\text { Seberapa pengaruh isu tersebut terkait } \\
\text { dengan nilai-nilai masyarakat, sosial, } \\
\text { politik, ekonomi, dan budaya? }\end{array}$ & 2 & 3 & 1 & 3 & 1 & 1 \\
\hline & Jumlah & $\mathbf{2 0}$ & $\mathbf{3 1}$ & $\mathbf{1 9}$ & $\mathbf{1 9}$ & $\mathbf{2 5}$ & $\mathbf{1 7}$ \\
\hline
\end{tabular}

Dari tahapan tes litmus yang sesuai dengan kategori didapat 3 isu yang dikategorikan sangat prioritas, cukup prioritas, dan operasional, sehingga diketahui isuisu strategis sebagai berikut:

Isu 2 yang merupakan Mengembangkan Objek Wisata dengan Menggandeng pihak lainnya seperti BUMN, Swast dan Masyarakat dikategorikan sebagai isu yang sangat prioritas

Isu 5 yaitu Meningkatkan Daya Tarik Objek Wisata dengan Atraksi Wisata di kategorikan isu yang cukup prioritas

Isu 1 Meningkat Mengembangkan Produk Wisata melalui Peningkatan Sarana dan Prasarana Sebagai penunjang objek wisata dikategorikan sebagai isu operasional.

\section{KESIMPULAN}

1. Kondisi Pengembangan Pariwisata terhadap Penerimaan Pendapatan Asli Daerah di Kabupaten Bangka.

Walaupun banyak objek wisata potensial di Kabupaten Bangka namun belum dikelola secara optimal. Untuk jumlah kunjungan wisatawan di Kabupaten Bangka tidak stabil setiap tahunnya karena mengalami kenaikan dan penurunan. Kondisi kelembagaan pariwisata di Kabupaten Bangka sudah cukup baik dimana banyak terdapat asosiasi kepariwisataan dan Lembaga-lembaga lain. Tetapi hal tersebut tidak diimbangi dengan kualitas sumber daya manusia dimana tingkat pendidikan aparatur kepariwisataan dan stakeholder yang terkait belum cukup secara kualitas maupun kuantitas. Pemasaran/ promosi pariwisata di Kabupaten Bangka sudah banyak dilakukan baik dengan media cetak maupun elektonik (internet). Karena karakteristik wisatawan yang datang untuk berwisata di Kabupaten Bangka adalah wisatawan local menyebabkan pemasaran wisata berfokus hanya pada kalangan wisatawan local dan wisatawan nusantara. Sedangkan pertumbuhan wisatawan masih belum konsisten dimana terdapat kenaikan dan penurunan jumlah kunjungan terlebih sejak tahun 2020 pada situasi pademi covid terdapat penurunan jumlah kunjungan sehingga sangat berdampak pada usaha pariwisata di Kabupaten Bangka yang pada akhirnya berkorelasi terhadap penerimaan dari pajak dan retribusi daerah sebagai komponen Pendapatan Asli Daerah di dalam APBD.

2. Faktor-faktor Yang Mempengaruhi Pengembangan Pariwisata Kabupaten Bangka

Faktor-faktor yang mempengaruhi perkembangan pariwisata di Kabupaten Bangka di 
bagi menjadi factor pendorong dan factor penghambat. Berdasarkan hasil penelitian ditemukan beberapa faktor yang menjadi pendukung/pendorong dalam pengembangan pariwisata di Kabupaten Bangka, yaitu: (1) Daya dukung Prasarana; (2) Daya dukung industri pariwisata; (3) Daya dukung masyarakat; (4) Kebijakan teknis pemerintah; (5) Kerjasama/kebijakan dengan pihak lain; (6) Keamanan dan keramahan penduduk setempat; (7) Keinginan berwisata dan berkreasi. Sedangkan faktor penghambat dalam pengembangan pariwisata di Kabupaten Bangka, yaitu: (1) Lemahnya Promosi dan Event Pariwisata; (2) Rendahnya SDM pariwisata; (3) Belum optimalnya pengembangan sarana dan prasarana; (4) Potensi wisata belum digali secara maksimal; (5) Rendahnya kesadaran masyarakat akan potensi wisata; (6) Adanya wisata lain yang sejenis; (7) Kerusakan dan Pencemaran Lingkungan; (8) Kurangnya kesadaran akan pariwisata

\section{Strategi yang dilakukan pada sektor pariwisata dalam rangka peningkatan Pendapatan Asli Daerah di Kabupaten Bangka.}

Berdasarkan identifikasi isu-isu dalam pengembangan pariwisata di kabupaten bangka yang dianalisis dengan metode SWOT dan kemudian dilakukan pengujian dengan tes litmus. Dari hasil tes tersebut dihasilkan 3 isu yang dikategorikan sangat prioritas, cukup prioritas, dan operasional. Adapun hasil tes litmus tersebut adalah sebagai berikut:

1. Mengembangkan Objek Wisata dengan berkerjasama pihak lainnya seperti BUMN, Swasta dan Masyarakat dikategorikan sebagai isu yang sangat prioritas

2. Meningkatkan Daya Tarik Objek Wisata dengan Atraksi Wisata di kategorikan sebagai isu yang cukup prioritas

3. Mengembangkan objek wisata melalui Peningkatan Sarana dan Prasarana Sebagai penunjang objek wisata dikategorikan sebagai isu operasional.

\section{SARAN}

Secara teoritis strategi pengembangan pariwisata dalam rangka peningkatan Pendapatan Asli Daerah yang telah dianalisis dengan pendekatan deskriptif harus dilakukan pembahasan lebih lanjut dengan pendekatan yang berbeda agar penelitian ini lebih komperhensif.

Secara praktis hal yang dapat dilakukan untuk meningkatkan strategi pengembangan pariwisata dalam rangka peningkatan Pendapatan Asli Daerah adalah Pemerintah daerah disarankan menerapkan strategi mengembangkan objek wisata dengan menggandeng pihak lain baik swasta, masyarakat maupun pemerintah (BUMN,BUMD, BUMDes). Pengelolaan kepriwisataan sangat mustahil dapat dilakukan oleh pemerintah daerah sendiri tanpa adanya dukungan dari masyarakat dan pihak lain mengingat komplektivitas usaha kepariwisataan. Usaha membangun pola kemitraan dengan menerapkan prinsip transparansi, akuntabel dan mutual benefit perlu dilaksanakan antara pemerintah daerah dan stakeholder lain dalam industry kepariwisataan. Selain itu disarankan memberikan alokasi anggaran yang cukup dan proposional kepada Dinas Pariwisata dan Kebudayaan sebagai leading sector dari pemerintah dalam pengelolaan kegiatan kepariwisataan serta membangun sarana dan prasarana yang menunjang industry kepariwisataan. Di era globalisasi pemerintah daerah didorong agar aktif dan kreatif dalam mengkemas Atraksi Wisata serta memasarkan secara masif dengan cara-cara yang professional. Tidak lupa membentuk SDM yang unggul dalam pengelolaan kepariwisataan baik dengan pola rekruitmen yang baik dan pelaksanaan Pendidikan dan pelatihan di bidang kepariwisataan dan tidak kalah pentingnya pemda dapat membuat regulasi yang menciptakan ekosistem yang baik dan menguntungkan bagi pelaku usaha di bidang pariwisata.

\section{DAFTAR PUSTAKA}

A, Yoeti, Oka. Edisi Revisi 1996, Pengantar Ilmu Pariwisata, Bandung: Angkasa.

Neuman,W.L, 2003, "Social Research Methods: Qualitative and Quantitative Approch", Allyn and Bacon, Boston

Rusidi, 2006. Metodologi Penelitian: Bahan Ajar pada Program Pascasarjana MAPD, Jatinangor, Bandung.

Simangusong, Fernandes, 2017. Metodologi Penelitian Pemerintahan, Alfabeta, Bandung. 
Sugiyono, 2010. Metode Penelitian Kuantitatif dan $R \&$ D. Alfabeta, Bandung. 